Why the Weather?

By Prof. Charles Franklin Brooks, with the collaboration of Eleanor Stabler Brooks and John Nelson. Revised and enlarged. Pp. xvii $+295+32$ plates. (London: Chapman and Hall, Ltd., 1935.) 10s. $6 d$. net.

THe author of this book, who is professor of meteoro. logy at Harvard University, has the rare gift of being able to write vividly and clearly about weather in its various aspects. The book under review is a second edition of a book which first appeared in 1924, and has now been amplified and rearranged. It aims at giving, in the simplest possible language, a description and explanation of almost all the phenomena of weather as observed in the United States of America, including depressions, anticyclones, tornadoes, thunderstorms, ice-storms, rainbows, haloes and many others. The descriptions are illustrated by a series of about fifty photographs, all very well reproduced. The explanations are in the main satisfactory, partly of course because the author has wisely avoided the topies which would involve him in difficult theory. That he is up-to-date is shown by the inclusion in his description of lightning of Schonland's account of the 'leader stroke' which initiates the discharge.

The arrangement of the book is very different from that usually followed, as is seen from the fact that the first mention of the constitution of the atmosphere comes on p. 195. The book is divided into four sections, one for each season of the year. In each section the weather of the season is described, and, so far as this is possible, explained. The terms employed are those in use in the United States, which occasionally differ from those used in the British Isles. A notable example of this is the use of the word 'sleet' to denote hard pellets of ice, instead of the mixture of snow and rain to which this name is given in England.

Throughout the book the bearing of weather on everyday life is emphasised. The order in which it is arranged is dictated by dramatic value rather than by any systematic theory; but, in view of the very complete index, there is no great disadvantage in this from the point of view of using the book for reference purposes. This is a welcome addition to the list of books on the subject of weather. D. B.

\section{Coloured Plates of the Birds of Ceylon}

By G. M. Henry. With a Short Description of each Bird by W. E. Wait. Part 4. Pp. iii $+16+16$ plates. (Colombo: Colombo Museum; London: Dulau and Co., Ltd., 1935.) $30 s$.

A WORD of praise must be given to this further fascicle of a work which is being published gradually by the Government of Ceylon, although it consists only of sixteen figures and a minimum of text. Mr. Henry's pictures are beautiful, and the subjects are mainly tropical species particularly worthy of illustration in colour: the plates have been well reproduced, in handsome format. The birds have not been selected in any obvious order, and the final extent of the work is said to be still undecided.
Wien-Harms Handbuch der Experimentalphysik Ergänzungswerk. Herausgegeben von M. Wien und G. Joos. Band 2: Beugungsversuche mit Materiewellen; Einführung in die Quantenmechanik. Von Prof. Dr. E. Fues. Pp. xv + 351. (Leipzig: Akademische Verlagsgesellschaft m.b.H., 1935.) 30 gold marks.

WHEN the Wien-Harms "Handbuch der Physik" was originally planned, very little was known concerning the diffraction of electrons, and it is obvious that some place had to be found for this subject in the "Ergänzungswerke", which will no doubt continue to be published at suitable intervals in order to keep this important work up-to-date. In like manner, quantum mechanics was in its infancy, and even in a series on experimental physics an introduction to its study had to be provided.

Both subjects have been very satisfactorily covered in the present volume by Dr. Fues. He has taken considerable pains to emphasise the wave mechanics point of viow in all the experimental features he describes. He gives a very good survey of the apparatus and technique of electron diffraction, which will be of signal use to those who are unfamiliar with the German literature; one would have expected, however, a little more recognition of English work, in particular, that of Finch. His account of the work on vapours is extremely good, and a very pleasing feature of the book is its wealth of photographic reproductions and other diagrams. The discussion of the index of refraction and allied phenomena is most instructive; so, too, are the discussions of the experiments with slow electrons and on the diffraction of atomic and molecular rays.

The introduction to quantum mechanics covers some two hundred pages, and gives a survey of the present state of the theory which will be found adequate for the requirements of most readers of the "Handbuch". The present volume maintains the high standard of printing and production which its precursors have set.

L. F. B.

\section{Initiation à la vie en Argentine}

Par Max Daireaux, L. Diffloth, Roberto Gache, Pierre Janet, Gaston Jèze, F. Legueu, G. Lewandowski et J.-H. Ricard. (Choses d'Amérique.) Pp. 192. (Paris: Armand Colin, 1935.) 12 francs.

THIs appreciation of modern Argentina is particularly interesting to English readers in the stress which it lays on Franco-Argentinian cultural relationships. There is full realisation of the virility of the young Argentinians, clever but perhaps too self-reliant in that they are tending to lose contact with their European colleagues in science, applied science, art and literature. On the other hand, in a somewhat superficial review of the position of science in Argentina, the close appreciation of French workers is emphasised. There is a note of jealousy in the references to the elaborate equipment of scientific institutions, and a rather arrogant assertion that all Argentinian literature is self-evidently a child of French parentage which contrasts with the condemnation of the snobbishness of the Argentinian intelligentsia in ignoring native art. 